\title{
The Problem-Based Learning: How the effect on student critical thinking ability and learning motivation in COVID-19 pandemic?
}

\author{
Rifqi Festiawan ${ }^{1 *}\left(\mathbb{1}\right.$, Lim Boon Hooi $^{2}{ }^{\circledR}$, Prisca Widiawati $^{3}$, I Ketut Yoda $^{4}$, \\ Adi $S^{5}$, Muhammad Sigit Antoni ${ }^{6}$, Arifin Ika Nugroho ${ }^{7}{ }^{(1)}$ \\ Universitas Jenderal Soedirman, Indonesia ${ }^{1 *}$ \\ Universiti Malaya, Malaysia ${ }^{2}$ \\ Universitas Negeri Malang, Indonesia ${ }^{3}$ \\ Universitas Pendidikan Ganesha, Indonesia ${ }^{4}$ \\ Universitas Nahdlatul Ulama Sunan Giri, Indonesia ${ }^{5}$ \\ Universitas Negeri Yogyakarta, Indonesia ${ }^{6}$ \\ Universitas Musamus, Indonesia ${ }^{7}$
}

Received: 09 February 2021; Accepted 22 April 2021; Published 30 July 2021

Ed 2021; 6(2): 231-243

\begin{abstract}
In the period of the Covid-19 pandemic, lecturers were confronted with difficulties to give a more intelligent learning model, one of which was a problem-based learning model. The reason for this investigation was to decide the impact of issue put together learning models with respect to understudies' basic reasoning abilities and acquiring inspiration, particularly in actual training learning. This exploration is a genuine test with a randomized pretest-posttest control bunch plan. The population is all understudies of class X, XI, and XII. The testing method utilizes straightforward irregular inspecting. The examples utilized in this examination were 112 individuals. The examination instrument utilized was target tests as various decision inquiries for basic reasoning abilities and mastering inspiration polls. The information investigation utilized was paired example ttest and Independent example t-test. The consequences of his exploration are there is an impact of issue put together learning models with respect to understudies' basic reasoning abilities. There is an impact of the issue put together learning model with respect to understudy inspiration. The problem-based learning model is more compelling than the immediate showing model for understudies' basic deduction abilities in actual schooling mastering. The model of problem-based learning has a more beneficial outcome than the immediate encouraging model on understudies' learning inspiration in actual schooling learning. From these outcomes, it very well may be presumed that there is an impact of issue put together learning with respect to basic reasoning abilities and understudy inspiration, and issue based learning shows better outcomes contrasted with direct educating.
\end{abstract}

Keywords: Problem-based learning; critical thinking; learning motivation; COVID-19

https://doi.org/10.25299/sportarea.2021.vol6(2).6393

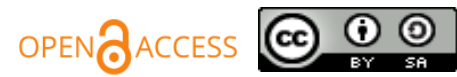

Copyright @ 2021 Rifqi Festiawan, Lim Boon Hooi, Prisca Widiawati, I Ketut Yoda, Adi S, Muhammad Sigit Antoni, Arifin Ika Nugroho

Corresponding author: Rifqi Festiawan, Department of Physical Education, Faculty of Health Sciences, Universitas Jenderal Soedirman, Purwokerto, Indonesia

Email: rifqi.festiawan@unsoed.ac.id

How to Cite: Festiawan, R., Hooi, L. B., Widiawati, P., Yoda, I. K., S, A., Antoni, M. S., \& Nugroho, A. I. (2021). The ProblemBased Learning: How the effect on student critical thinking ability and learning motivation in COVID-19 pandemic?. Journal Sport Area, 6(2), 231-243. https://doi.org/10.25299/sportarea.2021.vol6(2).6393 


\section{INTRODUCTION}

Education in the 21st century intends to construct understudies' insight capacities in figuring out how to have the option to tackle issues around them (Tan, 2017; Wicaksono et al., 2020). There are three main aspects in $21^{\text {st }}$ century, those are: learning and innovation skills, life and career skills, and digital literacy (Dupri et al., 2021). Critical thinking, creative thinking, communication, and collaboration are four indicators that sign learning and innovation skill that should be owned (Dupri et al., 2019). Shaping knowledge, in reality, isn't simply by knowing, yet it can take care of issues looked around the climate in an important, pertinent, and context-oriented way (Fery et al., 2017). Relevant understudy learning can prepare basic reasoning, dominating innovation, coordinating, and teaming up is exceptionally essential for tackling issues (Khoiriyah \& Husamah, 2018). The goals to be accomplished by understudies are exceptionally assorted, for instance, thinking abilities, social abilities, psychomotor abilities, and cycle abilities (Car et al., 2019; Eviyanti et al., 2017; Khusaini et al., 2018; McBride, 2016). The learning educational program additionally means to improve the nature of the creative mind and innovativeness; get human qualities, build up one's latent capacity, create basic reasoning, and build up a submitted and dependable individual (Astikasari et al., 2021; Festiawan \& Khurrohman, 2020; Heaviside et al., 2018). The current educational plan requests anticipate that understudies should have psychological abilities, capacities in reality, and have a respectable character, and be more dynamic in the learning interaction (Kogoya et al., 2021; Nurcahyo et al., 2021). In later learning, the instructor as the principal wellspring of data will transform into a more ideal student with genuine and understudy situated issues so understudies can build their insight and be effectively associated with discovering data (Endepohls-Ulpe, 2009; Fery et al., 2017; Lin et al., 2017; Wongdaeng \& Hajihama, 2018).

Discovering that prompts free adapting so understudies can develop their insight is as yet inadequate. This was found by scientists at the hour of perception at SMAN 2 Purwokerto, free learning had not been completely done and the administration of basic reasoning abilities had not been purposefully customized. Understudies are as yet reliant on the educator who goes about as the primary wellspring of data, this causes fatigue and less enabling understudies' basic reasoning abilities. Despite the fact that learning has been coordinated through Student Activity Sheets which expects to make learning not fixated on the educator, and in which there are conversation material and questions, there is consistently an instructor who actually has a great deal of jobs to tackle the issues introduced in the Student Activity Sheets. Supported on former search, no studies that explicitly examined the core of problem-based learning methods on critical thinking skills and learning motive in Covid-19 widespread in Banyumas. So the purpose of this cognate was to identify: (1) Knowing the effect of giving a problem-based learning methods on critical thinking skills, (2) Knowing the effect of problem-based learning methods on learning motivation, (3) To know the effect of direct teaching on critical thinking, (4) To know the effect of direct teaching on learning motivation.

The absence of complete understudy contribution in learning is on the grounds that understudies put forth little attempt in finding their data, and this decreases the importance of dynamic and successful learning (Burgess et al., 2018; Mann et al., 2021; Raiyn, 2016). Understudies will in general figure out how to have the option to address redundancy inquiries by remembering topic as opposed to comprehension, examining an issue, and tackling issues that might be confronted day by day so basic reasoning is ineffectively prepared (Malmia et al., 2019; Selvy et al., 2020). Therefore, regarding psychological likewise missing, as confirmed in the normal securing of learning results in the past capability is still not exactly the base competency standard, not rarely the educator should do healing. Endeavors to beat these issues need viable learning exercises in forming understudies to have the option to adapt freely without failing to remember the intellectual, emotional, and psychomotor perspectives, one of which is to utilize issue based learning.

The Problem-Based Learning (PBL) model is a learning model that has an understudy-focused learning measure, expects understudies to be dynamic in the learning interaction and builds up the capacity to tackle issues from everyday life, and invigorates understudies' reasoning capacities. This is following the explanation of Nurcahyo et al., (2020) and Ulger (2018) to be specific "In issue based picking up, learning focuses are understudies (understudy focused)". Besides, Narmaditya et al., (2017) stated that "Problembased learning $(\mathrm{PBL})$ is an understudy focused way to deal with realizing which empowers understudies to 
take an interest in little gathering work during the learning interaction to encourage further learning. The problem-based learning model is a learning technique to improve basic reasoning abilities and inspiration (Yustifar et al., 2021). Savery (2019) uncovered that "problem-based Learning (PBL) as a strategy for guidance to improve basic reasoning has been concentrated widely in the clinical field". As per Simamora, Sidabutar, and Surya (2017) stated that "PBL will unquestionably help improve basic speculation among understudies". Besides, Mumtaz and Latif (2017) said that "PBL effectively affects basic reasoning abilities". Likewise, Saputra et al., (2019) contended that "Few methodologies have been recommended in the writing to help sparks test, and one such methodology is problem-based learning (PBL)".

From research conducted by Masek and Yamin (2011) mention that (1) the specific processes in PBL theoretically support students' critical thinking development according to the design applied, (2) empirical evidence in general is inconclusive in explaining the effect of PBL on students' critical thinking ability, especially the studies outside of medical field, (3) some evidence indicates that PBL requires a long term exposure to foster students' critical thinking ability, (4) several predictors might also influence the relationships of PBL and critical thinking such as age, gender, academic achievement, and educational background, which calls for further research work. The implication is that, PBL curriculum must carefully be designed and concerned on the critical elements contributing to PBL effectiveness. This includes the roles of the facilitator in mediating students learning, particularly in triggering students' meta-cognitive thinking. With all these carefully considered, PBL may be successful as what has been noted in the theory.

The understudies in the PBL bunch have higher inspiration towards learning when contrasted with understudies in the talk gathering (Saqr et al., 2018). The immediate training model is a learning model that is regularly utilized by actual instruction instructors in every one of their learning at school (Febrianta et al., 2021). The immediate learning model (direct educating) is a learning model in which the instructor changes data or abilities straightforwardly to understudies and mastering is arranged towards the objectives trained by the educator, while understudies are just as objects of the instructor's data conveyance (Major \& Mulvihill, 2018; Wijaya et al., 2021). The use of problem-based learning is currently widely used, but there have been no studies using this method during the Covid-19 pandemic to measure critical thinking skills and learning motivation in Banyumas district, so this research can become a new reference for education in Banyumas district. In view of the portrayal over, this examination explores the impact of issue put together learning models with respect to the capacity to think fundamentally and understudies' learning inspiration in actual instruction learning.

\section{METHODS}

The research method utilized in this investigation utilizes the true experimental research technique. The examination configuration utilized in this investigation was The Randomize Pretest-Posttest Control Group Design. This plan includes two gatherings that were concentrated to be utilized as the trial gathering and the benchmark group. The two gatherings were estimated twice, to be specific at the pretest and posttest. Coming up next is an outline of this plan:

Table 1. The Randomize Pretest-Posttest Control Group

\begin{tabular}{ccccc}
\hline Group & \multicolumn{3}{c}{ Treatment Design } \\
\hline Experimental Group & $\mathrm{R}$ & $\mathrm{O} 1$ & $\mathrm{X}$ & $\mathrm{O} 2$ \\
$\mathrm{R}$ & $\mathrm{O} 1$ & $\mathrm{C}$ & $\mathrm{O} 2$ & $\mathrm{R}$ \\
\hline
\end{tabular}

(Sugiyono, 2012)

Description:

$\mathrm{R}$ : Assignment

O1 : An initial test using multiple-choice test and poll questions

$\mathrm{O} 2$ : Final test using multiple-choice test and poll

$\mathrm{X}$ : Treatment (Application of problem-based learning model in PE learning)

C : Conventional Learning (the application of Direct teaching models in PE learning) 
The explanation the analysts utilized the trial technique with the Randomize Pretest-Posttest Control Group Design configuration was to see the degree of the consequences of the treatment of the issue based learning model in the trial gathering to improve basic reasoning abilities and understudy inspiration to acquire actual training.

\section{Population}

The population in this examination was all understudies of class X, XI, and XII in SMA Negeri 2 Purwokerto which comprised of 1201 understudies partitioned into 36 classes. Each level, to be specific class $\mathrm{X}$ and class XI comprises of 12 classes. Examining in this investigation utilized straightforward irregular testing and acquired an all-out example of 112 understudies. A sample of 112 people was obtained by purposive sampling technique with several criteria.

\section{Research Procedures}

The research procedure carried out was to provide treatment to the treatment group for 8 meetings, for 4 weeks through an online learning media platform, by applying the problem-based learning method to students, who were accompanied directly by their parents. While the control group was not given treatment or only with conventional learning. Each group was given a pretest before treatment and posttest after the treatment process was complete.

\section{Instrument}

The instruments used in this study consisted of 2 instruments, namely the instrument of critical thinking skills and learning motivation. Assessing students' critical thinking skills is used an instrument of critical thinking ability Sari et al., (2019) and an instrument for measuring learning motivation is SMTSL Tuan et al., (2005) comprised of six appraisal pointers videlicet 1) Self-viability 2) Active learning system 3) Science learning esteem 4) Performance objectives 5) Achievement objectives 6) Learning climate incitement. The instrument was a poll with 5 estimating scales utilizing a Likert scale from answers 1 (unequivocally deviate) to 5 (emphatically concur). The instrument had been approved in substance and build. The Cronbach alpha figuring of six markers was 0.870 . The Pearson relationship figuring number went from $0.09-0.51$.

\section{Data Collection Technique}

An instrument or estimating instrument to gather information on examination results is required in each investigation, so it is important to have an information assortment strategy so the information acquired can be trusted and delegate. The main information assortment is done toward the start of the gathering before treatment is given as beginning information, and the second is done toward the finish of the gathering after treatment is given as the last information. This depends on the exploration configuration utilized in this investigation, in particular The Randomize Pretest-Posttest Control Group Design (Fraenkel, Wallen and Hyun, 2012). The accompanying information assortment strategies in this investigation: 1) Questions and polls are given to tests during actual schooling learning, 2) Questions and surveys are finished by tests during actual instruction learning, 3) Questions and surveys are gathered, 4) Researchers lead an assessment of inquiries and surveys, and the subsequent score is an investigation of basic reasoning abilities and understudy inspiration.

\section{Data Analysis}

Information examination was completed utilizing the Statistical Package for Social Science (SPSS) arrangement 21 program. The means taken were as per the following: 1) Data ordinariness test, Data ordinariness test was done to get data about the ordinariness of the information got. Additionally, the information ordinariness test will decide the means that should be taken straight away, specifically what factual examination ought to be utilized is to enter and investigate utilizing the investigate information depiction in the SPSS 21 arrangement menu. Information in particular: Kolmogorov Smirnov and Shapiro 
Wilk. For the ordinariness test, the analyst alludes to the Kolmogorov Smirnov examination. 2) Homogeneity Test information is completed after the information ordinariness test. The motivation behind the information homogeneity test is to discover that the information comes from homogeneous examples. Additionally, it is likewise to figure out what kind of measurable investigation is additionally utilized in theory information testing. The means taken to test the homogeneity of information utilizing the SPSS 21 arrangement programming program are equivalent to the information ordinariness test. The yield created from the enlightening investigate of the information additionally delivers two dissects, in particular the ordinariness and homogeneity of the information. 3) Hypothesis Testing Hypothesis test information is performed to get ends from the information got. The kind of factual examination used to test speculations to discover ends is controlled by the consequences of ordinariness and homogeneity test information. In this speculation test, the scientist needs to take a gander at parts of basic reasoning abilities and understudy inspiration when treatment (pretest and posttest) by utilizing a model of issue based learning and ordinary (direct educating). Speculation estimation utilizes Paired Samples T-Test to discover the huge impact between the two models.

\section{RESULTS AND DISCUSSIONS \\ Research Results}

The data obtained in this study is the value of students' critical thinking and creative thinking skills, with the following data description:

\section{Data on Students' Critical Thinking Ability}

Critical thinking ability data was obtained through written tests in the form of problem descriptions with a total of 6 items covering aspects of critical thinking abilities including interpretation, analysis, inference, evaluation, explanation, and self-regulation. The results of the distribution and descriptive data of students' critical thinking abilities can be seen in table 2 and table 3 .

Table 2. Student Critical Thinking Ability Data

\begin{tabular}{ccccc}
\hline \multirow{2}{*}{ No } & \multirow{2}{*}{ Interval Value } & \multirow{2}{*}{ Middle Value } & \multicolumn{2}{c}{ Frequency } \\
\cline { 4 - 5 } 1 & $41-48$ & 44,5 & Control Class & Experimental Classes \\
2 & $49-56$ & 52,5 & 5 & 0 \\
3 & $57-64$ & 60,5 & 10 & 0 \\
4 & $65-72$ & 68,5 & 20 & 4 \\
5 & $73-80$ & 76,5 & 2 & 18 \\
6 & $81-88$ & 84,5 & 1 & 14 \\
7 & $89-96$ & 92,5 & $\mathbf{5 6}$ & 5 \\
\hline \multicolumn{7}{r}{ Total } & & & $\mathbf{5 6}$ \\
\hline
\end{tabular}

From table 2, it can be known the frequency of the largest control class lies in the value 65 until the value 72 and the middle value 68.5. The frequency of the largest experimentation class lies at 73 to 80 and the middle value of 84.5 . This indicates that the level of values for the experiment class is higher than the control class.

Table 3. Data on Students' Critical Thinking Ability

\begin{tabular}{cccc}
\hline No & Aspects & Control Class & Experimental Classes \\
\hline 1 & Interpretation & 69.12 & 79.41 \\
2 & Analysis & 63.24 & 81.62 \\
3 & Inference & 68.38 & 87.50 \\
4 & Evaluation & 60.29 & 88.24 \\
5 & Explanation & 64.71 & 75.74 \\
6 & Self-regulation & 75.74 & 86.03 \\
\hline
\end{tabular}


Table 3 shows that the average value of aspects of students' critical thinking skills in the experimental class was higher than in the control class. The highest increase in the average value of the control and experimental class is in the evaluation aspect. Achievement of the highest value of the average control class and experiment contained in the evaluation aspect. The lowest increase in the average value of the control and experiment class is found in the aspects of Interpretation and Self-regulation. Achievement of the lowest value of the average control and experimental class is in the evaluation.

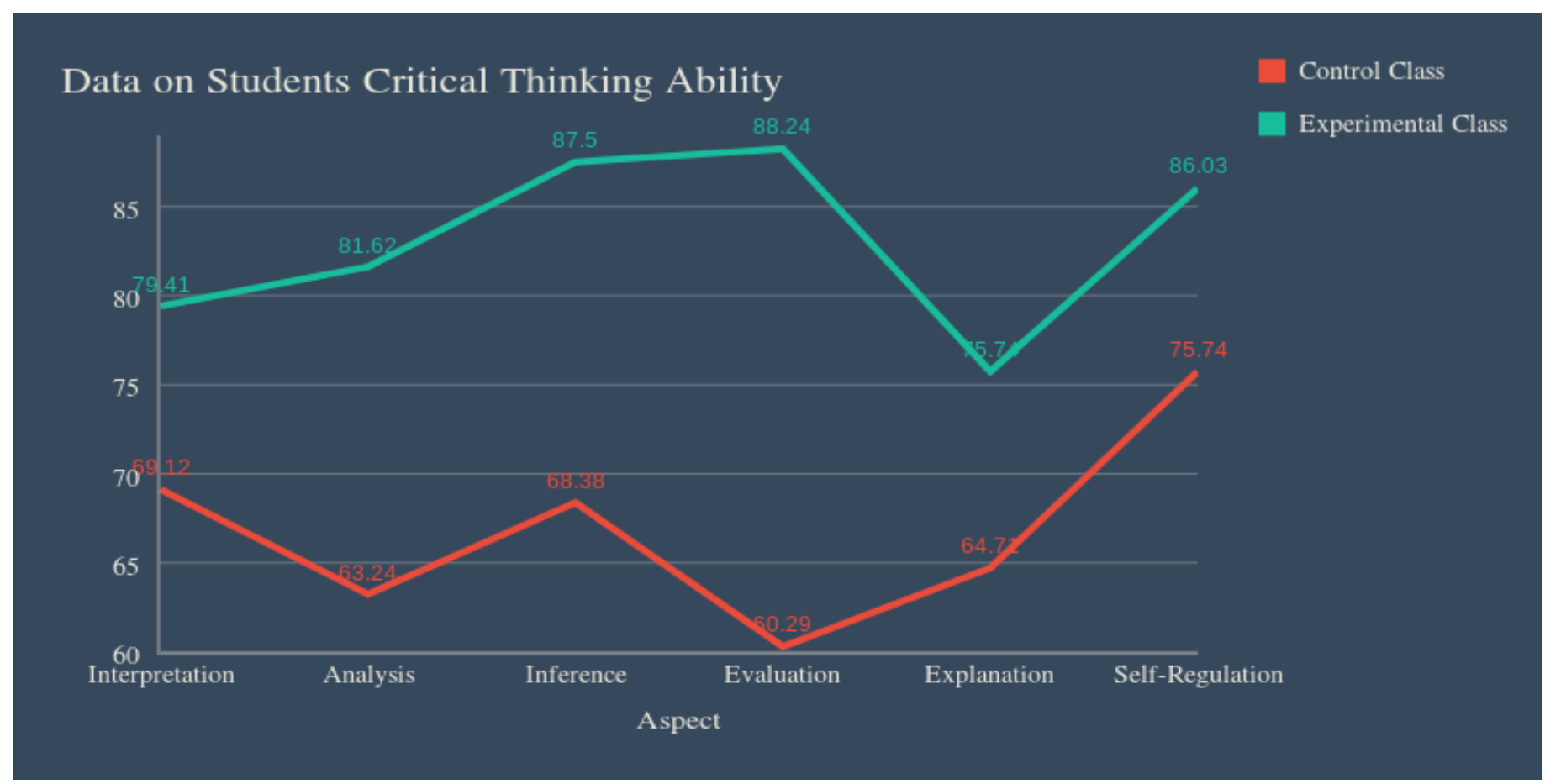

Figure 1. Data on Students' Critical Thinking Ability

\section{Student Learning Motivation Data}

Data distribution results and descriptive data on students' motivation can be seen in Table 4 below.

Table 4. Student Motivation Data

\begin{tabular}{ccccc}
\hline \multirow{2}{*}{ No } & Interval Value & Middle Value & Control Class & Frequency \\
\cline { 4 - 5 } & $41-48$ & 44,5 & 20 & Experimental Class \\
2 & $49-56$ & 52,5 & 10 & 0 \\
3 & $57-64$ & 60,5 & 8 & 7 \\
4 & $65-72$ & 68,5 & 15 & 13 \\
5 & $73-80$ & 76,5 & 1 & 15 \\
6 & $81-88$ & 84,5 & 2 & 17 \\
7 & $89-96$ & 92,5 & 0 & 4 \\
\hline & Total & & $\mathbf{5 6}$ & $\mathbf{5 6}$ \\
\hline
\end{tabular}

From table 4 above, it can be seen that the frequency of the largest control class lies in the value of 65 to 72 and the middle value of 68.5. The frequency of the largest experimental class lies in grades 81 to 88 and the middle value is 84.5 . This shows that the grade level for the experimental class is higher than the control class. 


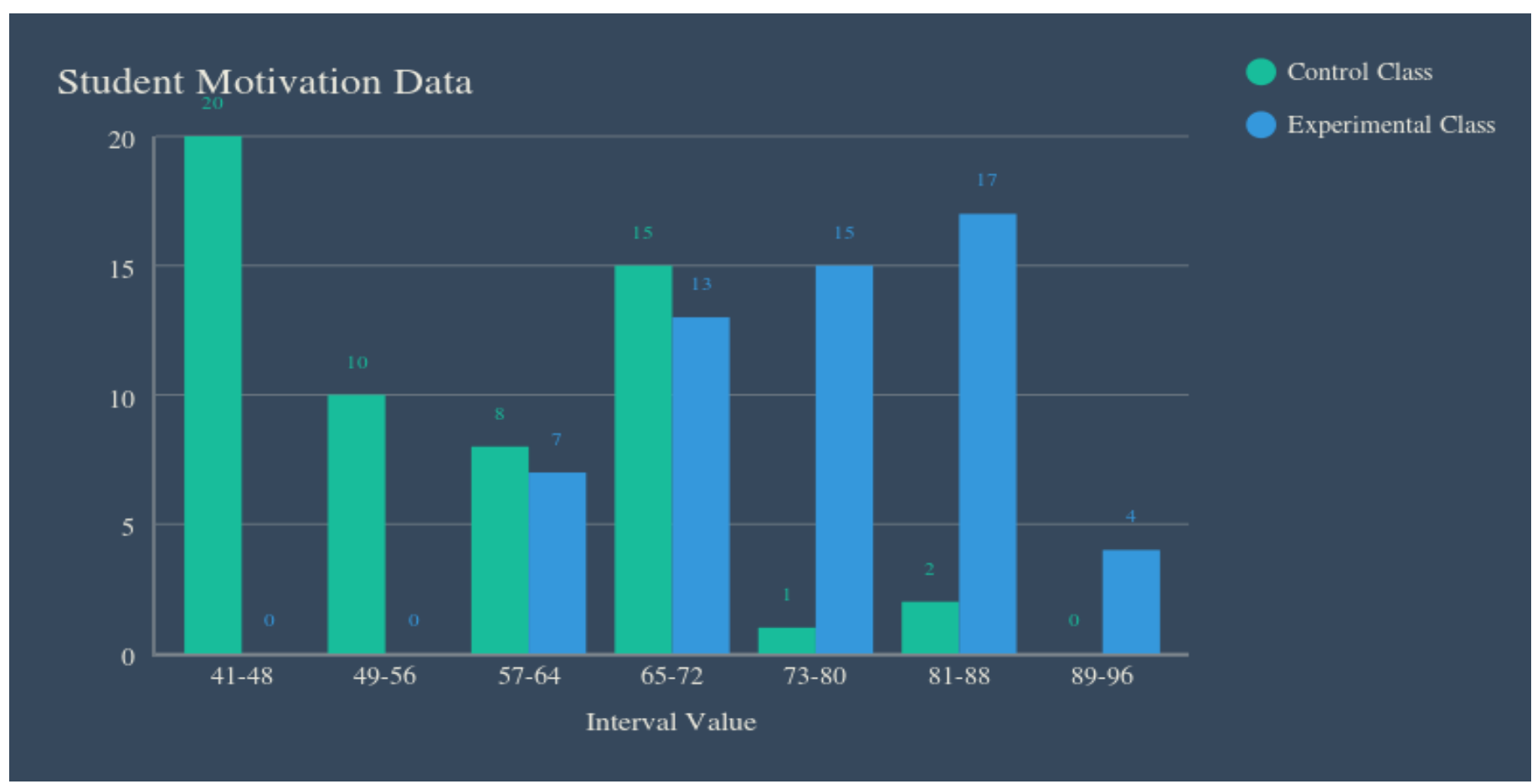

Figure 2. Data on Students Motivation Data

\section{Prerequisite Test}

The prerequisite test consists of a normality test and a homogeneity test, the data obtained include:

\section{Normality Test}

In this study the normality test was carried out using SPSS 24 with the Shapiro Wilk test, the data were normally distributed if the significance value was greater than 0.05 or (Sig>0.05), conversely if the data were smaller than 0.05 or (Sig. < 0.05 ) then the data is said to be abnormal. The following is a table of normality test results:

Table 5. Data normality test results

\begin{tabular}{ccccc} 
Data & Statistic & Df & Sig & \multicolumn{1}{c}{ Conclusion } \\
\hline Pretest Control Group &, 989 & 20 &, 981 & Normal \\
Posttest Control Group &, 941 & 20 &, 564 & Normal \\
Pretest Experimental Group &, 944 & 20 &, 675 & Normal \\
Posttest Experimental Group &, 919 & 20 &, 347 & Normal \\
\hline
\end{tabular}

The data table above shows that the Sig values of the pretest and posttest of the control and experimental groups are all greater than 0.05 or Sig values $>0.05$, it can be concluded that the data are normally distributed.

\section{Homogeneity Test}

A homogeneity test is a test carried out to determine the similarity of the study population variants. Homogeneity testing was carried out with the help of the SPSS computer program. The decision making criteria are if the sign value $>0.05$ or $t$ arithmetic $<\mathrm{t}$ table, means that the sample is homogeneous.

Table 6. Test Results of Data Homogeneity

\begin{tabular}{cccccc}
\hline Data & Levene Statistic & df1 & df2 & Sig & Conclusion \\
\hline Pretest Control Group &, 256 & 1 & 18 &, 873 & Homogeneous \\
Postest Control Group &, 465 & 1 & 18 &, 736 & Homogeneous \\
Pretest Group Experiments &, 289 & 1 & 17,395 &, 786 & Homogeneous \\
Postest Experimental Group &, 490 & 1 & 18 &, 797 & Homogeneous \\
\hline
\end{tabular}


From the calculation, it is obtained the signature of the pretest and postest homogeneity test table of the control and experimental groups above both groups getting Sig values above 0.05 or Sig. $>0.05$ and these results indicate that the sample variant is homogeneous.

\section{Hypothesis Testing}

The data analysis technique used is using the t-test with a significance level of 5\%. There are two types of $\mathrm{t}$-tests, namely different samples (independent sample t-test) and similar samples (dependent sample t-test). This test is to find out the differences in the mean of two independent population/data groups.

Table 7. Test Result Paired T-Test

\begin{tabular}{|c|c|c|c|c|c|c|c|c|c|}
\hline & & \multicolumn{5}{|c|}{ Paired Differences } & \multirow{3}{*}{$\mathbf{t}$} & \multirow{3}{*}{ df } & \multirow{3}{*}{$\begin{array}{c}\text { Sig. } \\
\text { (2-tailed) }\end{array}$} \\
\hline & & \multirow[t]{2}{*}{ Mean } & \multirow[t]{2}{*}{$\begin{array}{c}\text { Std. } \\
\text { Deviation }\end{array}$} & \multirow[t]{2}{*}{$\begin{array}{l}\text { Std. Error } \\
\text { Mean }\end{array}$} & \multicolumn{2}{|c|}{$\begin{array}{l}95 \% \text { Confidence } \\
\text { Interval of the } \\
\text { Difference }\end{array}$} & & & \\
\hline & & & & & Lower & Upper & & & \\
\hline Pair 1 & $\begin{array}{l}\text { Pretest control Group } \\
\text { Posttest control Group }\end{array}$ & $-6,200$ & 1,851 & ,554 & $-4,649$ & $-1,237$ & $-4,573$ & 19 & ,002 \\
\hline Pair 2 & $\begin{array}{l}\text { Pretests Group Experiments } \\
\text { Posttest Experimental Group }\end{array}$ & $-6,700$ & 1,949 & ,578 & $-5,108$ & $-1,832$ & $-5,169$ & 19 &, 000 \\
\hline
\end{tabular}

Based on the above table, the results of Sig. (2-tailed) control group pre-test and post-test are 0.002 and the results of Sig. (2-tailed) the pre-test and post-test experimental groups were 0,000. With these results, the two groups have a Sig. $<0.05$ and can be interpreted that there is a significant influence both the control group and the experimental group on critical thinking skills and learning motivation.

\section{Discussion}

In light of the choice of the $\mathrm{H} 0$ test dismissed, at that point, there is the impact of the Problem-based Learning model on understudies' basic speculation abilities in mastering science. The after effects of the test choice have appeared from the worth (sig) that is 0.001 so that (sig) $<0.05$. This is likewise upheld by the normal estimation of parts of basic reasoning capacity which shows an expansion in table 4.3 so the normal estimation of basic speculation abilities there is a moderately huge distinction that is 66.91 in the control class and 76.95 in the trial class, with a normal contrast normal, is 10.4. The normal estimation of understudies' basic reasoning abilities got by the trial class with the Problem-based Learning model is higher than the control class that utilizes ordinary learning with fluctuated addresses. That is on the grounds that, through the Problem-based Learning model, understudies effectively consider perceiving problems, communicating thoughts of critical thinking, directing examinations to answer problems experienced, looking for answers to problems experienced until investigating and assessing critical thinking measures. The critical thinking measure is related to understudies' day by day problems. That is, understudies have the chance to figure out how to tackle the problems they face in regular day to day existence. At the point when understudies tackle problems that address genuine occasions, they will take part in reasoning conduct. Understudies are dynamic intending to a given problem so it trains understudies to have the option to think basically. Learning with the Problem-based Learning model can cultivate the capacity to think in utilizing bits of knowledge had without pondering the nature of the assessments communicated. So understudies can unreservedly build up their reasoning abilities. The instructor doesn't give as much data to understudies yet assists understudies with creating thinking capacities, critical thinking, and scholarly abilities. The object of the exercise isn't gained distinctly in coursebooks however from issues that encompass it.

Other research results that are in line are research from (Major \& Mulvihill, 2018; Selvy et al., 2020) which stated that problem-based learning has been shown to improve students' critical thinking skills $(p=$ $0.001)$ and student learning motivation $(p=0.000)$. When instructors are actualizing the learning model, understudies frequently utilize an assortment of abilities, critical thinking techniques, and basic reasoning (Anazifa \& Djukri, 2017; Wyness \& Dalton, 2018). Learning with the Problem-based Learning model starts with the phases of understudy direction to the issue. Understudies perceive the issue by giving an image of a 
reality which is an issue followed by a few inquiries posed to understudies. In this action, understudies can distinguish issues that are found and discover answers for these issues. This is steady with the assertion from Chis et al., (2018); Zeliha, (2017) which uncovered that to get an answer, they were required to effectively look for the data required from different sources. Data can be gotten from understanding material, asset people, etc. The after effects of this examination demonstrate that the Problem-based Learning model whose learning interaction depends on issues can improve understudies' basic reasoning abilities. This is upheld by the consequences of exploration directed by Astriani et al., (2017) which shows that there are huge contrasts between the learning results of gatherings of understudies with high basic reasoning capacities instructed by the PBL strategy, which are higher than those of understudies with high basic reasoning capacities educated with customary techniques. Kim et al., (2018); Malmia et al., (2019); Myungsuk et al., (2018) included his exploration that shows that there are contrasts in the improvement of basic reasoning abilities and relational abilities between understudies who figure out how to utilize issue-based learning models with understudies who get ordinary learning.

\section{CONCLUSION}

From the consequences of the examination, it tends to be inferred that the problem-based learning model positively affects understudies' basic speculation abilities in actual instruction mastering, and then the problem-based learning model positively affects understudy inspiration in actual schooling learning, the problem-based learning model has a more constructive outcome as opposed to the immediate showing model of understudies 'basic intuition abilities in actual training acquiring, and the problem-based learning model has more sure impact than the immediate encouraging model on understudies' learning inspiration in actual schooling learning. In this study, there are limitations, namely the implementation of the problembased learning method that uses an online learning system, so that the ability of students to understand the material can vary, the suggestion for further research is to be able to try using a hybrid learning system in applying the problem-based learning method to measure other variables.

\section{REFERENCES}

Anazifa, R. D., \& Djukri. (2017). Project- based learning and problem- based learning: Are they effective to improve student's thinking skills? Jurnal Pendidikan IPA Indonesia, 6(2), 346-355. https://doi.org/10.15294/jpii.v6i2.11100

Astikasari, I. B., Rachman, H. A., Festiawan, R., Budi, D. R., \& Asnaldi, A. (2021). The Game Model To Develop Motor Skills For Kindergarten Students. Ann Trop Med \& Public Health, 24(3), 1-6. https://doi.org/10.36295/ASRO.2021.24315

Astriani, N., Surya, E., \& Syahputra, E. (2017). The Effect Of Problem-based Learning To Students' Mathematical Problem Solving Ability. International Journal Of Advance Research And Innovative Ideas In Education, 3(2), 3441-3446.

Burgess, A., Roberts, C., Ayton, T., \& Mellis, C. (2018). Implementation of modified team-based learning within a problem-based learning medical curriculum: A focus group study. BMC Medical Education, 18(1), 1-7. https://doi.org/10.1186/s12909-018-1172-8

Car, L. T., Myint Kyaw, B., Dunleavy, G., Smart, N. A., Semwal, M., Rotgans, J. I., Low-Beer, N., \& Campbell, J. (2019). Digital problem-based learning in health professions: Systematic review and metaanalysis by the digital health education collaboration. Journal of Medical Internet Research, 21(2), 112. https://doi.org/10.2196/12945 
Chis, A. E., Moldovan, A. N., Murphy, L., Pathak, P., \& Muntean, C. H. (2018). Investigating Flipped Classroom and Problem-based Learning in a programming module for computing conversion course. Educational Technology and Society, 21(4), 232-247.

Dupri., Nazirun, N., \& SM, N. R. (2019). Penerapan Model Problem-based Learning Untuk Meningkatkan Keterampilan Berpikir Kritis Pada Pendidikan Jasmani. Journal Sport Area, 4(2), 318. https://doi.org/10.25299/sportarea.2019.vol4(2).3760

Dupri, Nazirun, N., \& Candra, O. (2021). Creative Thinking Learning of Physical Education: Can Be Enhanced Using Discovery Learning Model? Journal Sport Area, 6(1), 37-47. https://doi.org/10.25299/sportarea.2021.vol6(1).5690

Endepohls-Ulpe, M. (2009). Teaching Gifted and Talented Children. In International Handbook of Research on Teachers and Teaching. https://doi.org/10.1007/978-0-387-73317-3_57

Eviyanti, C. Y., Surya, E., Syahputra, E., \& Simbolon, M. (2017). Improving the Students' Mathematical Problem Solving Ability by Applying Problem-based Learning Model in VII Grade at SMPN 1 Banda Aceh Indonesia. International Journal of Novel Research in Education and Learning, 4(2), 138-144.

Febrianta, Y., Sukoco, P., Sugiyanto, F. X., \& Festiawan, R. (2021). The Effectiveness of the Development of Rhythmic Activity Model of the Barongan Dance Modification for Physical Education Learning In Primary School. Ann Trop Med \& Public Health, 24(3). https://doi.org/10.36295/ASRO.2021.24305

Fery, M. F., Wahyudin, \& Tatang, H. (2017). Improving primary students mathematical literacy through problem-based learning and direct instruction. Educational Research and Reviews, 12(4), 212-219. https://doi.org/10.5897/err2016.3072

Festiawan, R., \& Khurrohman, M. F. (2020). Implementation of Higher Order Thinking Skills In Physical Education Learning In Covid-19 Era: Is It Work?. COMPETITOR: Jurnal Pendidikan Kepelatihan Olahraga, 13(2), 139-153. https://doi.org/10.26858/cjpko.v13i2.20158

Fraenkel, J. R., Wallen, N. E., \& Hyun, H. H. (2012). How to design and evaluate research in education. New York: MC Graw Hill Open University Press.

Heaviside, H. J., Manley, A. J., \& Hudson, J. (2018). Bridging the gap between education and employment: A case study of problem-based learning implementation in postgraduate sport and exercise psychology. Higher Education Pedagogies, 3(1), 463-477. https://doi.org/10.1080/23752696.2018.1462095

Khoiriyah, A. J., \& Husamah, H. (2018). Problem-based learning: Creative thinking skills, problem-solving skills, and learning outcome of seventh grade students. Jurnal Pendidikan Biologi Indonesia, 4(2), 151-160. https://doi.org/10.22219/jpbi.v4i2.5804

Khusaini, K., Lestari, S., \& Agustin, N. A. (2018). The Application of Problem-Based Learning Methods to Improve Economic Learning Outcomes and Motivation. Dinamika Pendidikan, 13(2), 218-227. https://doi.org/10.15294/dp.v13i2.16634

Kim, N. J., Belland, B. R., \& Walker, A. E. (2018). Effectiveness of Computer-Based Scaffolding in the Context of Problem-Based Learning for Stem Education: Bayesian Meta-analysis. Educational Psychology Review, 30(2), 397-429. https://doi.org/10.1007/s10648-017-9419-1 
Kogoya, T., Mutohir, C., Pramono, M., \& Festiawan, R. (2021). Application of Cooperative Learning Models Jigsaw Type for Improving Learning Outcomes Groundstroke Forehand Tonnis. Ann Trop Med \& Public Health, 24(3). https://doi.org/10.36295/ASRO.2021.24370

Lin, M. H., Chen, H. C., \& Liu, K. S. (2017). A study of the effects of digital learning on learning motivation and learning outcome. Eurasia Journal of Mathematics, Science and Technology Education, 13(7), 3553-3564. https://doi.org/10.12973/eurasia.2017.00744a

Major, T., \& Mulvihill, T. M. (2018). Problem-based learning pedagogies in teacher education: The case of Botswana. Interdisciplinary Journal of Problem-Based Learning, 12(1). https://doi.org/10.7771/15415015.1543

Malmia, W., Makatita, S. H., Lisaholit, S., Azwan, A., Magfirah, I., Tinggapi, H., \& Umanailo, M. C. B. (2019). Problem-based learning as an effort to improve student learning outcomes. International Journal of Scientific and Technology Research, 8(9), 1140-1143. https://doi.org/10.5281/zenodo.3457426

Mann, L., Chang, R., Chandrasekaran, S., Coddington, A., Daniel, S., Cook, E., Crossin, E., Cosson, B., Turner, J., Mazzurco, A., Dohaney, J., O’Hanlon, T., Pickering, J., Walker, S., Maclean, F., \& Smith, T. D. (2021). From problem-based learning to practice-based education: a framework for shaping future engineers. European Journal of Engineering Education, 46(1), $27-47$. https://doi.org/10.1080/03043797.2019.1708867

Masek, B. A., \& Yamin, S. (2011). The effect of problem-based learning on critical thinking ability in mathematics education. International Review of Social Sciences and Humanities, 2(1), 215-221. https://doi.org/10.1088/1742-6596/1157/4/042063

McBride, R. E. (2016). Critical Thinking-An Overview with Implications for Physical Education. Journal of Teaching in Physical Education, 11(2), 112-125. https://doi.org/10.1123/jtpe.11.2.112

Mumtaz, S., \& Latif, R. (2017). Learning through debate during problem-based learning: An active learning strategy. Advances in Physiology Education, 41(3), 390-394. https://doi.org/10.1152/advan.00157.2016

Myungsuk, K., Park, Y. J., Choi, S., \& Lee, S. J. (2018). The Effect of PBL (Problem-based Learning) on Academic Resilience, Learning Flow, and Academic Motivation of Nursing Students. Journal Pf The Korea Academia-Industrial Cooperation Society, 19(6), 291-298. https://dx.doi.org/10.1016/j.cirp.2016.06.001\%0

Narmaditya, B. S., Wulandari, D., \& Sakarji, S. R. B. (2017). Does Problem-Based Learning Improve Critical Thinking Skills? Cakrawala Pendidikan, 32(3), 14-21. https://doi.org/10.21831/cp.v38i3.21548

Nurcahyo, P. J., Festiawan, R., Budi, D. R., Listiandi, A. D., Ngadiman, N., \& Syafei, M. (2020). Rules and Routines in Covid-19: How Are The Applications In Physical Education Learning In School? Jurnal Menssana, 5(2), 130-138. https://doi.org/10.24036/MensSana.050220.05

Nurcahyo, P. J., Festiawan, R., Yoda, I. K., Wijayanto, A., \& Gustiputungurahadi, I. (2021). Study In Banyumas District: Is The Learning Materials Of Football In School Already Oriented To High Order Thinking Skill ? Ann Trop Med \& Public Health, 24(3). https://doi.org/10.36295/ASRO.2021.24366 
Raiyn, J. (2016). The Role of Visual Learning in Improving Students' High-Order Thinking Skills. Journal of Education and Practice, 7(24), 115-121.

Saputra, M. D., Joyoatmojo, S., Wardani, D. K., \& Sangka, K. B. (2019). Developing critical-thinking skills through the collaboration of Jigsaw model with problem-based learning model. International Journal of Instruction, 12(1), 1077-1094. https://doi.org/10.29333/iji.2019.12169a

Saqr, M., Fors, U., \& Nouri, J. (2018). Using social network analysis to understand online problem-based learning and predict performance. PLoS ONE, 13(9), 1-20. https://doi.org/10.1371/journal.pone.0203590

Sari, R., Sumarmi, S., Astina, I., Utomo, D., \& Ridhwan, R. (2019). Measuring students scientific learning perception and critical thinking skill using paper-based testing: School and gender differences. International Journal of Emerging Technologies in Learning, 14(19), 132-149. https://doi.org/10.3991/ijet.v14i19.10968

Savery, J. R. (2019). Comparative Pedagogical Models of Problem-Based Learning. In The Wiley Handbook of Problem-Based Learning. https://doi.org/10.1002/9781119173243.ch4

Selvy, Y., Ikhsan, M., Johar, R., \& Saminan. (2020). Improving students' mathematical creative thinking and motivation through GeoGebra assisted problem-based learning. Journal of Physics: Conference Series, 1460(1). https://doi.org/10.1088/1742-6596/1460/1/012004

Simamora, R. E., Sidabutar, D. R., \& Surya, E. (2017). Improving Learning Activity and Students' Problem Solving Skill through Problem-based Learning (PBL) in Junior High School. International Journal of Sciences: Basic and Applied Research (IJSBAR), 33(2), 321-331.

Sugiyono. (2012). Metode Penelitian Kuantitatif, Kualitatif dan R \& D. Bandung: Alfabeta.

Tan, O. S. (2017). Learning Using Problems to Power. Gale Cengage Learning.

Tuan, H. L., Chin, C. C., \& Shieh, S. H. (2005). The development of a questionnaire to measure students' motivation towards science learning. International Journal of Science Education, 27(6), 639-654. https://doi.org/10.1080/0950069042000323737

Ulger, K. (2018). The effect of problem-based learning on the creative thinking and critical thinking disposition of students in visual arts education. Interdisciplinary Journal of Problem-Based Learning, 12(1), 3-6. https://doi.org/10.7771/1541-5015.1649

Wicaksono, P. N., Kusuma, I. J., Festiawan, R., \& Widanita, N. (2020). Evaluasi penerapan pendekatan saintifik pada pembelajaran pendidikan jasmani materi teknik dasar passing sepak bola Evaluation of application of scientific approach in physical education learning basic technical material for football passing. Jurnal Pendidikan Jasmani Indonesia, 16(1), 41-54. https://doi.org/10.21831/jpji.v16i1.29774

Wijaya, M. A., Kanca, I. N., Yoda, I. K., Swadesi, I. K. I., \& Festiawan, R. (2021). Improving Professionalism of Physical Education Teachers in Bali Province by Using a Lesson Study Model based on Balinese Local Wisdom. Ann Trop Med \& Public Health, 24(3). https://doi.org/10.36295/ASRO.2021.24332 
Wongdaeng, M., \& Hajihama, S. (2018). Perceptions of Project-Based Learning on Promoting 21 st Century Skills and Learning Motivation in a Thai EFL setting. JSEL, 13(2), 158-190.

Wyness, L., \& Dalton, F. (2018). The value of problem-based learning in learning for sustainability: Undergraduate accounting student perspectives. Journal of Accounting Education, 45, 1-19. https://doi.org/10.1016/j.jaccedu.2018.09.001

Yustifar, A., Rachman, H. A., Festiawan, R., Yoda, I. K., \& Suwiwa, I. G. (2021). The Application of Problem-Based Learning In Physical Educations To Improve Learning Outcomes A Game of Volleyball Class X SMA N 1 Sleman. Ann Trop Med \& Public Health, 24(3). http://doi.org/10.36295/ASRO.2021.24320

Zeliha, N. B. (2017). The problem-based learning process: Reflections of pre-service elementary school teachers. Educational Research and Reviews, 12(4), 177-188. https://doi.org/10.5897/err2016.3045 